\title{
Buried with sickles: early modern interments from Drawsko, Poland
}

\author{
Marek Polcyn ${ }^{1} \&$ Elżbieta Gajda ${ }^{2}$
}

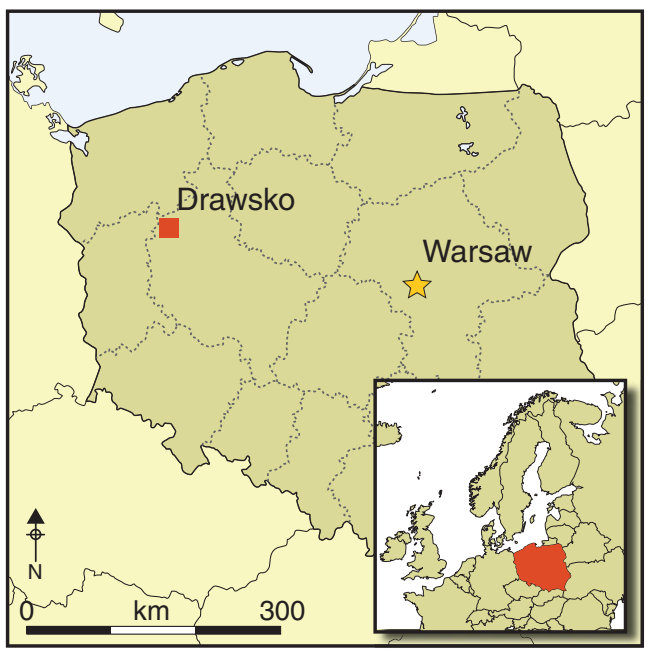

In Central Europe, medieval and early modern burials sometimes contain iron sickles placed on the body or in direct contact with the deceased. Previous interpretations have considered them as markers of social status or occupation, or as magical and apotropaic. Detailed analysis of sickle burials from a cemetery at Drawsko in Poland leads to a discussion of demonology beliefs, dual faith and a resurgence in paganism following the Counter-Reformation. The results illustrate how the sickle might have served as an indicator of social identity, the nature of the individual's death and the way the deceased was perceived within their community.

Keywords: Poland, Early Modern period, funerary rites, sickle burials, demonology, folklore

\section{Introduction}

Iron sickles with semi-circular and elliptical blades were common agricultural tools used to harvest grasses and cereals in Central Europe from the tenth to thirteenth centuries AD; they are frequently found in archaeological contexts of this period (Niesiołowska-Wędzka 1975: 173). These sickles occur mainly in waterlogged contexts, particularly among the remains of wooden piers and bridges crossing lakes (Rajewski 1974; Chudziak 2005). Iron sickles from funerary sites of the Middle Ages and later periods are significantly fewer and their preservation is often much poorer (Reichenbach 2004a; Chudziak 2005; Borzova 2006; Kurasiński \& Janowski 2010).

Here we present five unique burials with sickles from an early modern cemetery in north-west Poland. In four of these the sickles were placed on the bodies of the dead with the cutting edge tightly against the throat, while the fifth was located on the pelvis. Such an unusual funerary practice has placed the evidence from the Drawsko burials in a discourse of the so called 'archaeology of fear', which often cites necrophobia (fear of the dead) as an explanation for uncommon mortuary practices (Tsaliki 2008: 1-2). Burials

1 Department of Anthropology, Lakehead University, 955 Oliver Road, Thunder Bay, Ontario P7B5E1, Canada (Email:mpolcyn@lakeheadu.ca)

2 Muzeum Ziemi Czarnkowskiej, Wroniecka Street 32, 64-700, Czarnków, Poland 
that are marked by the inclusion of unusual items, or where the bodies have been placed in peculiar positions - particularly where they have been mutilated or dismembered - are often viewed as evidence for 'anti-vampiric' practices or simply as the graves of 'vampires' (see e.g. Stanaszek 1998; Żydok 2004). This phenomenon has received critical attention highlighting the range of alternative interpretations (see Koperkiewicz 2010; Gardeła \& Kajkowski 2013).

In addition to presenting the evidence for deposition of sickles in funerary contexts at Drawsko, we offer a preliminary overview of the available interpretations before applying aDNA analyses. We believe that, unlike the other graves at Drawsko, the burials with sickles can tell us about the social status of the dead, and the role they might have played in the local community. We will refer to ethnographic data, especially Polish folk demonology, which offers an opportunity to discuss the lifestyles of these individuals and the possible circumstances of their deaths; this might help determine their social identity and the reason for their peculiar burials.

\section{The site}

The cemetery site is located on a sandy hill, in Drawsko village in the Wielkopolska province of Poland, and excavations have been ongoing since 2008. It contains the remains of cremation burials from the Bronze Age as well as pit graves dated to the first and second centuries $\mathrm{BC}$, which were largely destroyed by the seventeenth century inhumation cemetery (Dernoga \& Gajda 2004). Before investigations began, the site was commonly believed to be an epidemic cemetery, but archaeological excavations at Drawsko have disproved this, revealing no evidence for mass graves or hasty burials. So far, we have revealed more than 250 burials including those with sickles, which were ordinary in every other respect, but we expect many more as the excavated area (currently $540 \mathrm{~m}^{2}$ ) expands. The distribution of graves in the excavated area is fairly uniform; the majority are oriented east-west following the Christian tradition of placing the head towards the west (Figure 1). The bodies are laid in a supine position with arms alongside the body or crossed over the chest or abdomen. Graves are rectangular; in many of them the staining or imprinted outlines of wooden coffins are preserved. No architectural structures or markers of a structured organisation of burial plots have been discovered to date. The chronology of the cemetery is indicated by the presence of copper coins minted by the Polish king, Jan Kazimierz (1648-1668). Apart from coins, sometimes preserved only as green stains, other grave goods are rare; they include single beads from rosaries or images of saints (medallions). Some child burials contain bronze or iron pins used to fasten garments or collars at the neck.

\section{The dead with sickles}

Burials with iron sickles were found in different parts of the cemetery; the graves with sickles share the same alignment as others in the cemetery (Figure 1). Osteological investigation revealed very little evidence of traumatic injuries, bone deformation, disease or dietary deficiencies. The skeletons with sickles have minimal levels of degenerative joint disease and do not differ from the ordinary burials, which overall represent very good health conditions

(C) Antiquity Publications Ltd, 2015 


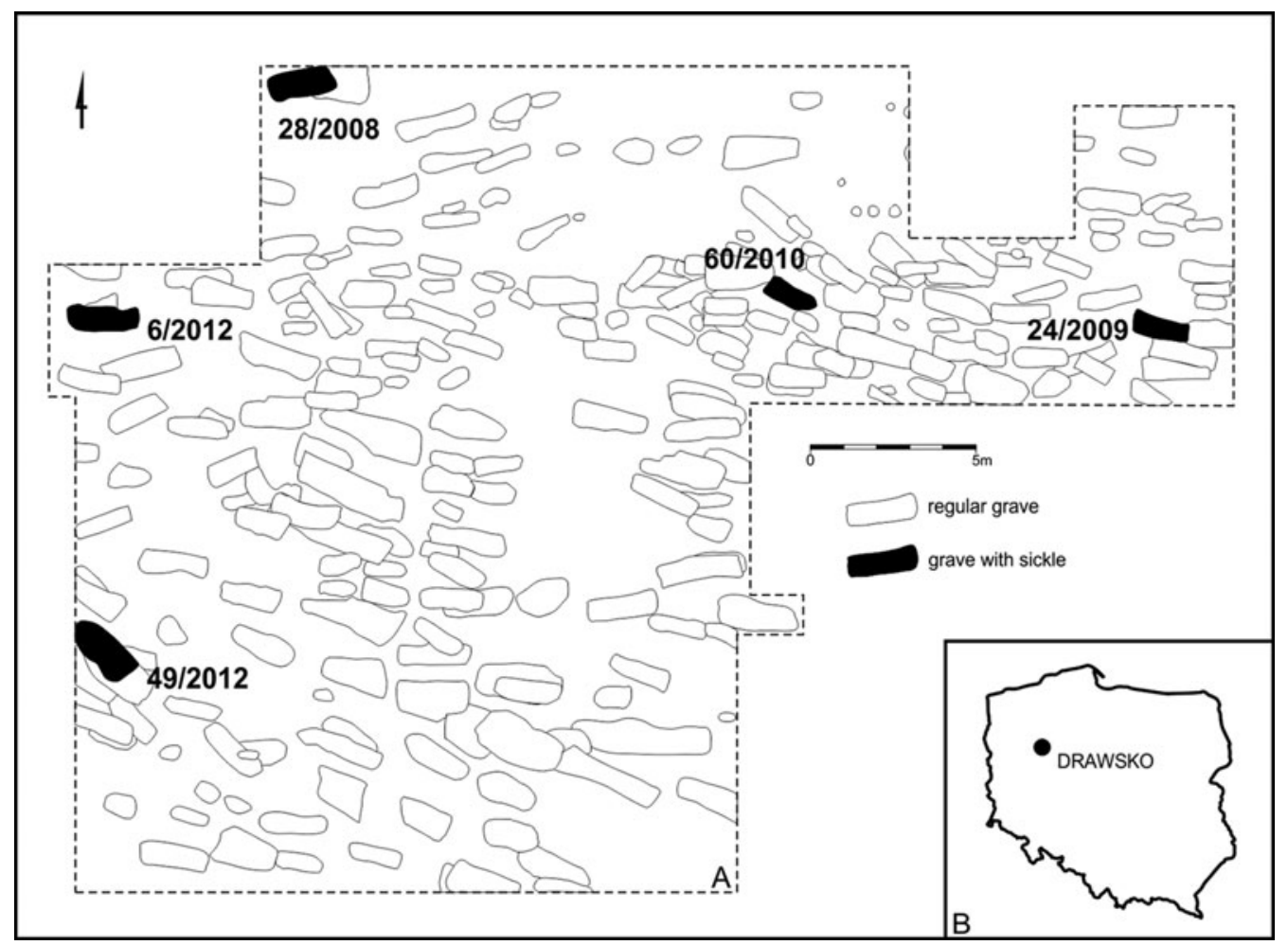

Figure 1. Drawsko, site 1: a) location of the graves with sickles; b) site location in Poland.

(Betsinger 2013). The Drawsko burials are very uniform and it is only the presence of sickles and their peculiar positioning that makes five of the burials so exceptional.

Grave 28/2008, located on the north-west edge of the study area, contained the moderately well-preserved skeleton of an adult male who died at the age of 35-44 years (Figure 2). A small iron sickle with a short blade and poorly discernible handle had been placed across the throat. Copper staining close to the skull suggests a coin was also present. The outline of the coffin is preserved.

Grave 24/2009, located in the eastern part of the study area, contained the moderately well-preserved skeleton of an adult female who died at 35-39 years of age (Figures $3 \& 4$ ). The skull is heavily crushed, probably by recent agricultural activities at the site. Across the throat, just below the jaw, a bow-shaped sickle was placed with a symmetrical blade and an easily discernible handle touching the right temple. Copper staining close to the skull is again indicative of a coin. The outline of the coffin is preserved.

Grave 60/2010, located in the central part of the study area, was that of an adult female aged 50-60 years (Figures 5 \& 6). A large, arch-curved sickle lay across the woman's hips. A well-preserved handle pointed upwards along the right hip, with the blade facing the upper part of the body. A medium-sized stone was placed on the throat, partly overlapping the sternum. The deceased female suffered ante-mortem tooth loss. Copper staining in the oral cavity indicates that she was buried with a coin in her mouth. Again, the outline of a wooden coffin is present. 


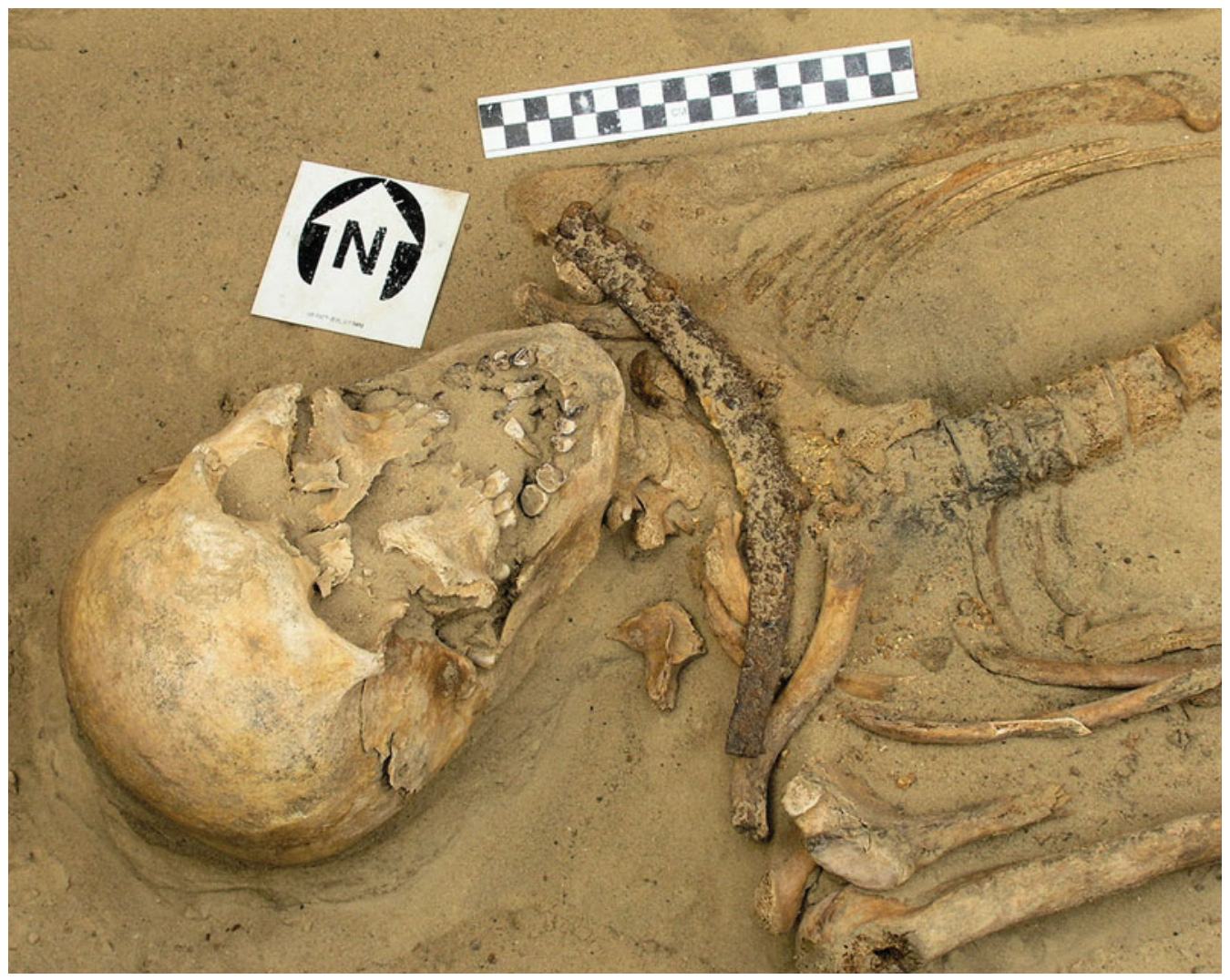

Figure 2. Skeleton of an adult male (28/2008) with a sickle on the throat.

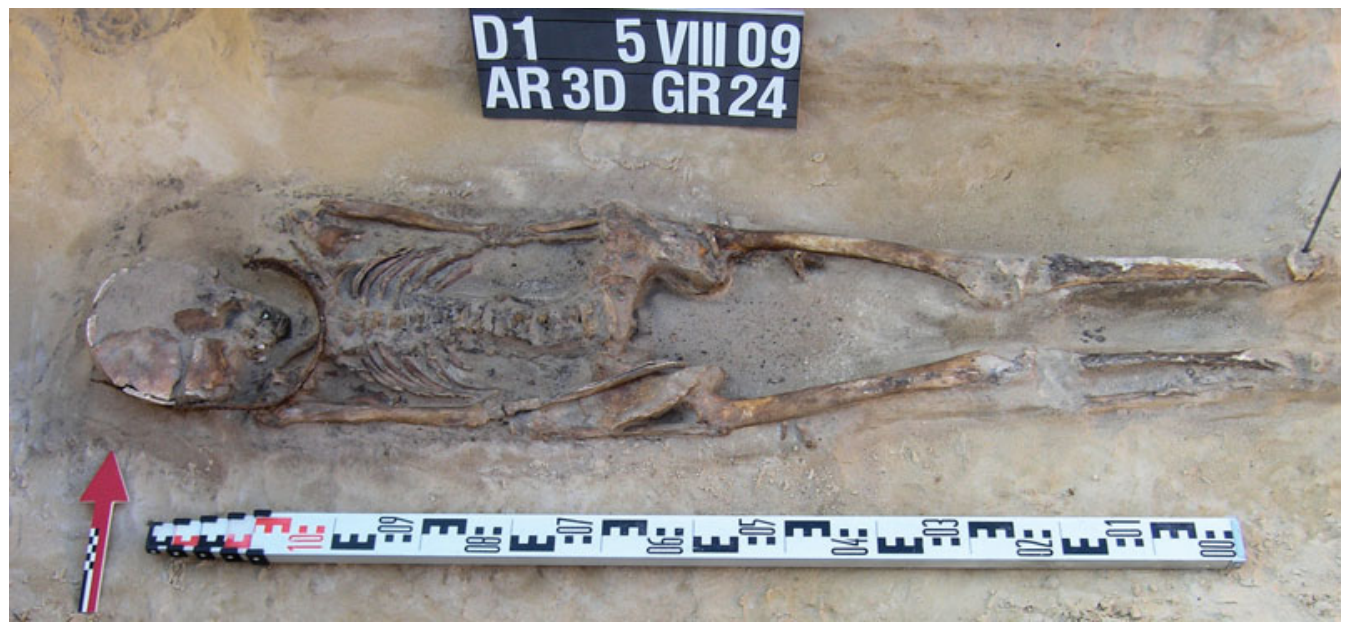

Figure 3. Skeleton of an adult female (24/2009) with a sickle on the throat.

C) Antiquity Publications Ltd, 2015 


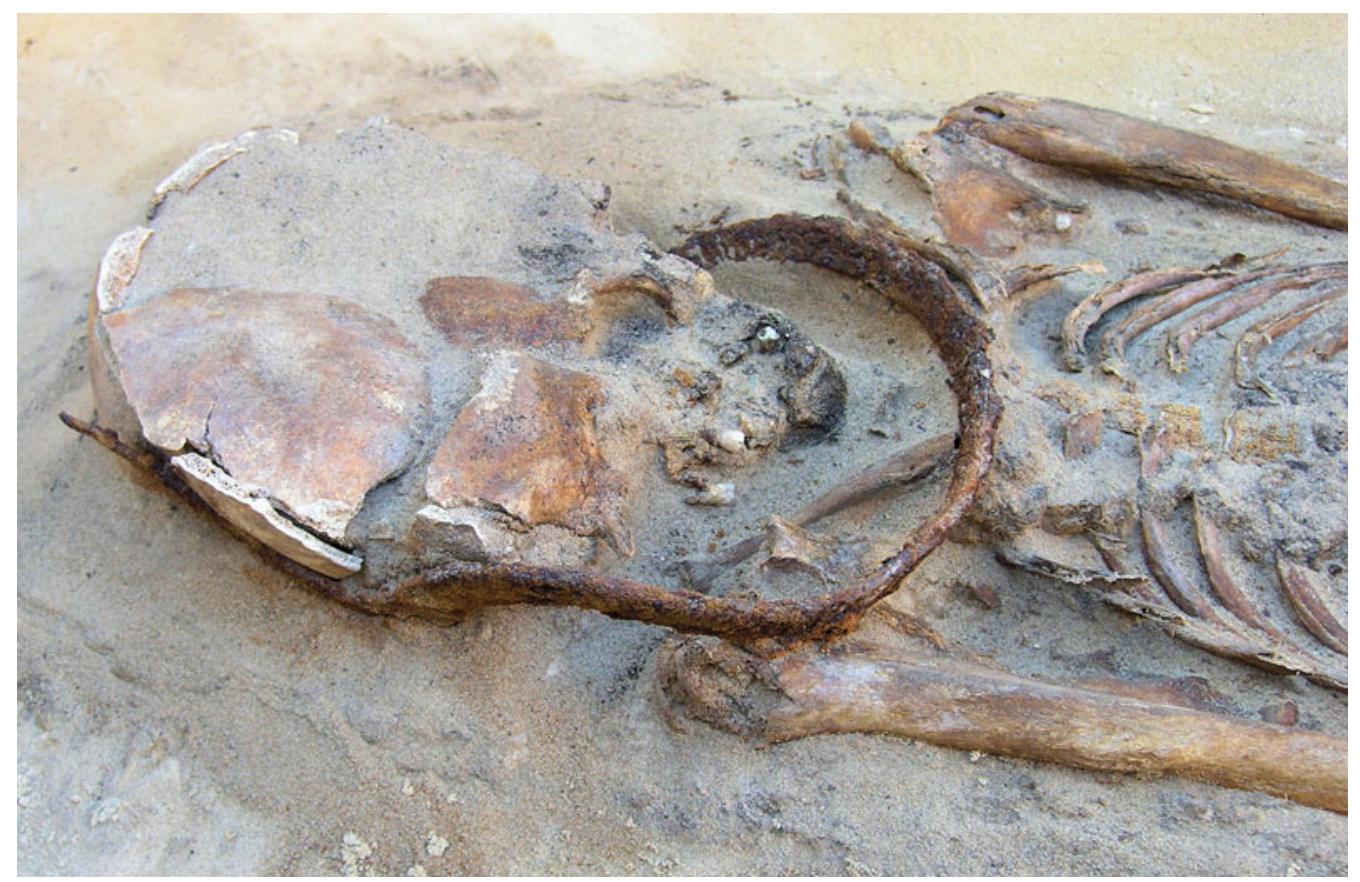

Figure 4. Skeleton of an adult female (24/2009) with a sickle on the throat.

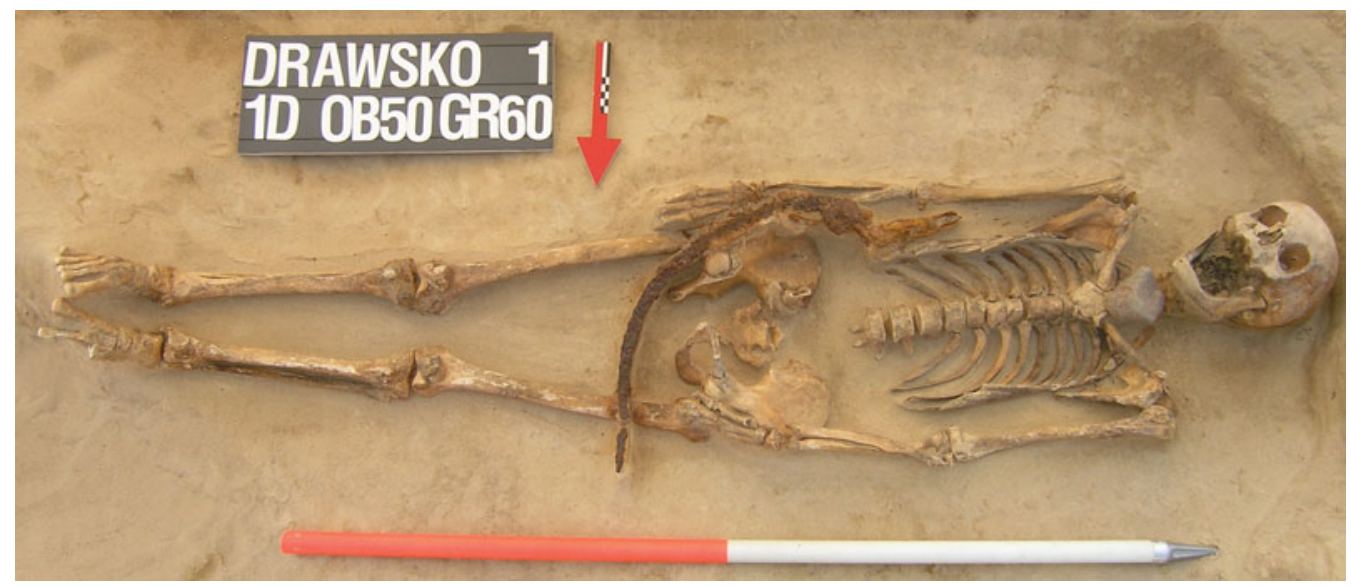

Figure 5. Skeleton of a toothless female (60/2010) with a sickle over the pelvis, a stone on the throat and a copper coin in the mouth.

Grave 6/2012, located on the western edge of the study area, contained the skeleton of an adolescent female who died at the age of 14-19 years (Figures 7 \& 8). A large, bowshaped sickle with an asymmetrical blade lay across her throat, just underneath the chin. The small handle fragment pointed upwards in close proximity to the left temple. The teeth are preserved perfectly. The deceased female was buried with a copper headband running over the top of her head. A copper coin was present below the left mandible. The outline of a wooden coffin can be seen. 


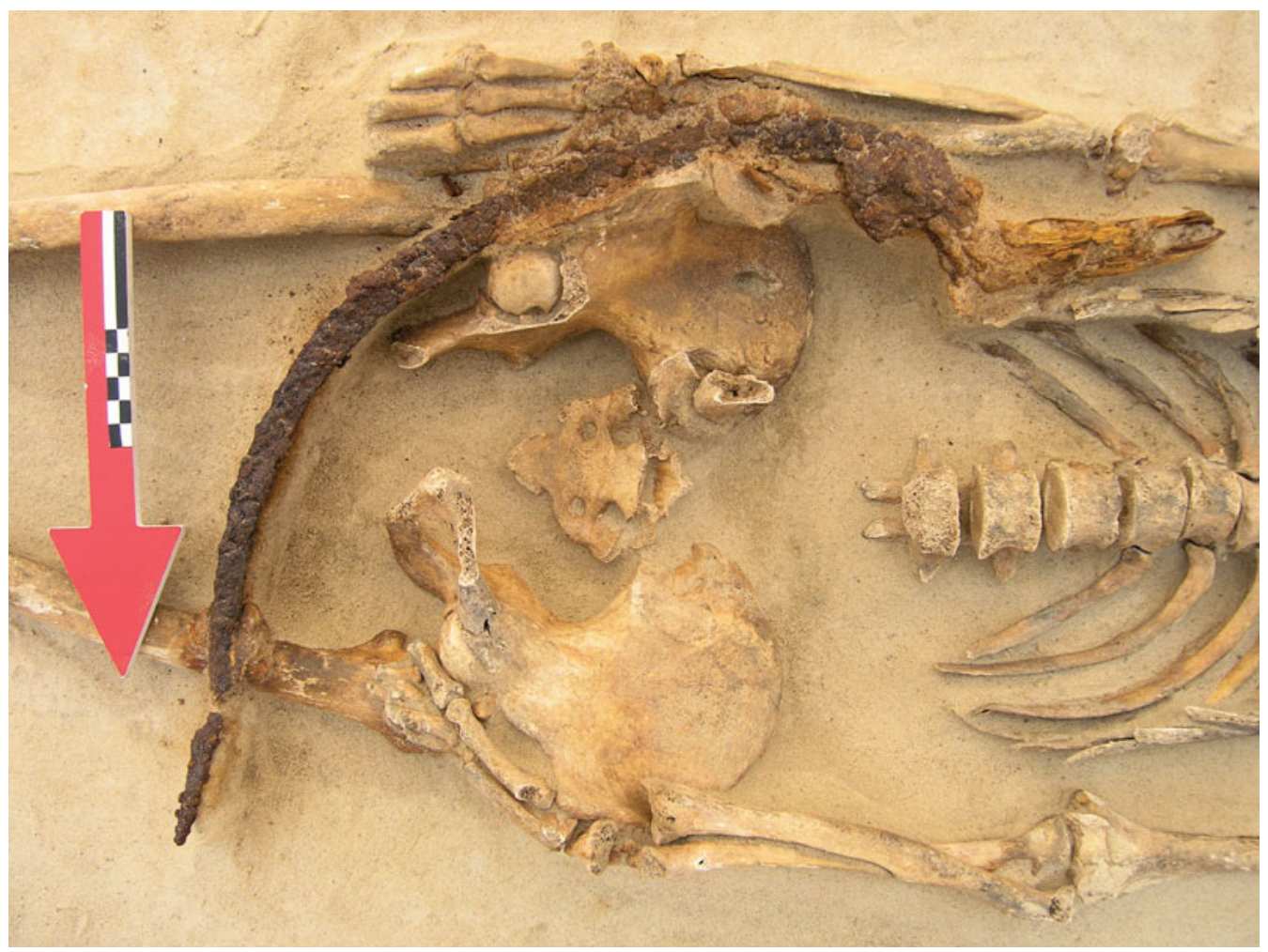

Figure 6. Skeleton of a toothless female (60/2010) with a sickle over the pelvis.

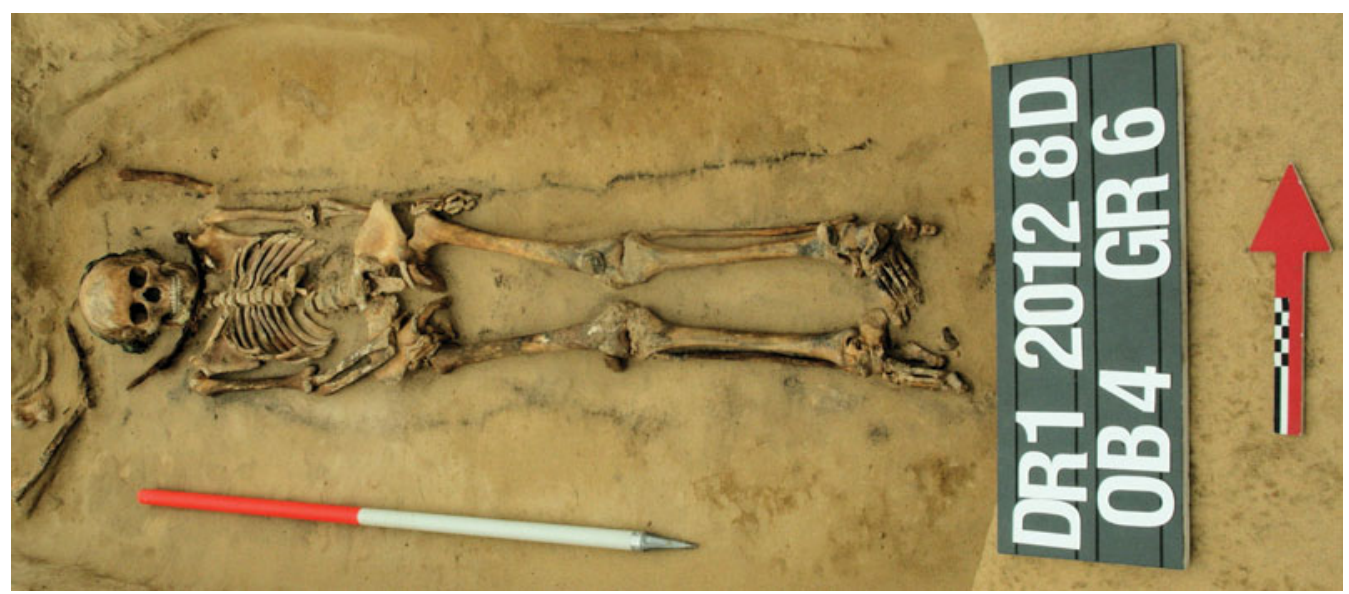

Figure 7. Skeleton of a teenage girl (6/2012) with a sickle on the throat, a copper headband across the skull and a copper coin below the mandible, noticeable is the outline of a wooden coffin.

(C) Antiquity Publications Ltd, 2015 


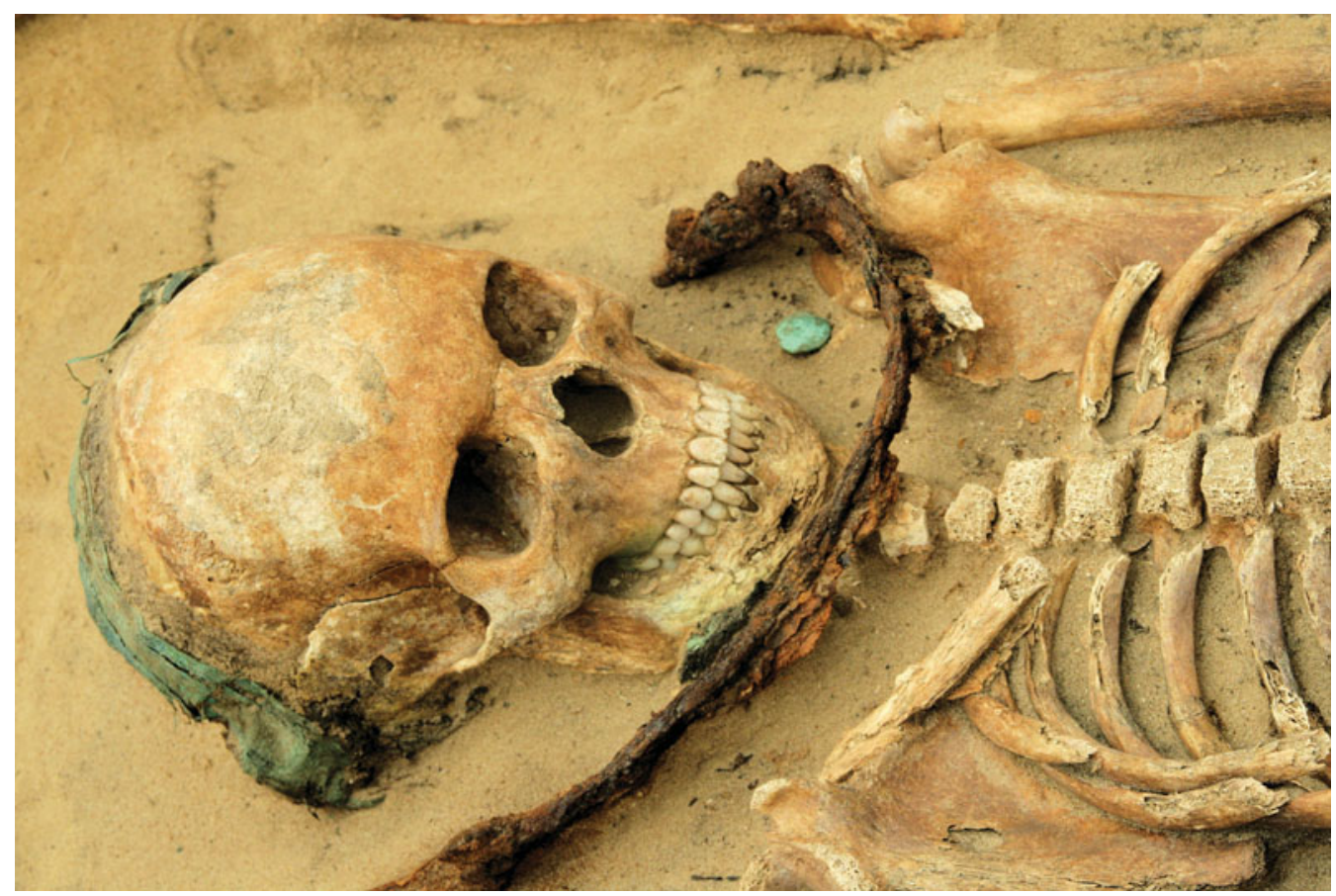

Figure 8. Skeleton of a teenage girl (6/2012) with a sickle on the throat, a copper headband across the skull and a copper coin below the mandible.

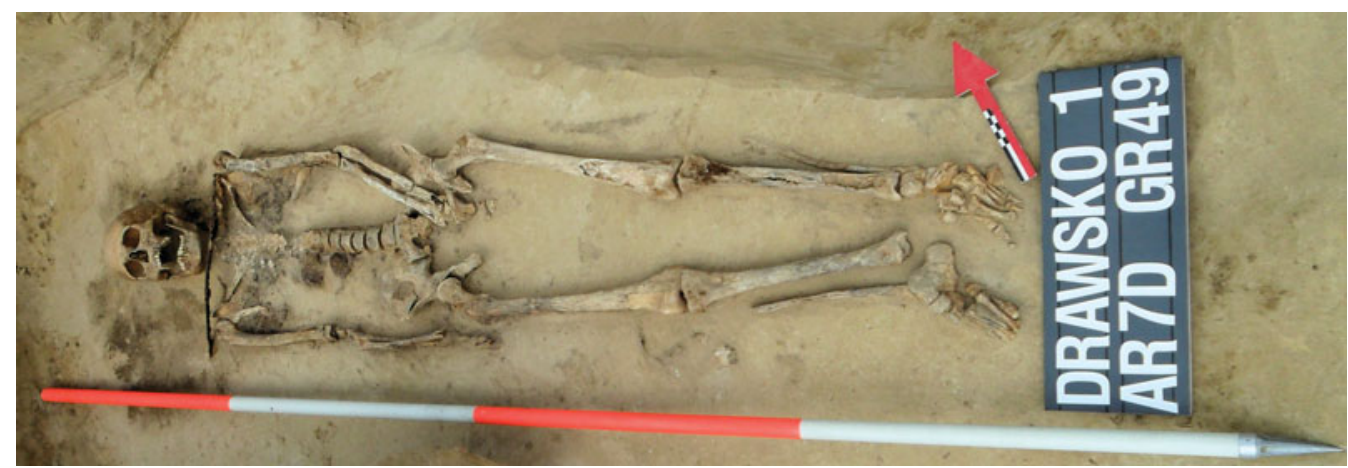

Figure 9. Skeleton of an adult female (49/2012) with a sickle on the throat.

Grave 49/2012, located in the south-west zone of the study area, was that of an adult female who died at the age of 30-39 years (Figures $9 \& 10$ ). A large sickle with an elongated, gently curved, asymmetrical blade lay across the throat of the deceased. The handle of the tool, which was not preserved, must have pointed upwards along the left side of the skull. Copper staining visible on the teeth of the lower mandible indicates that she was buried with a coin in her mouth. The outline of a wooden coffin is present. 


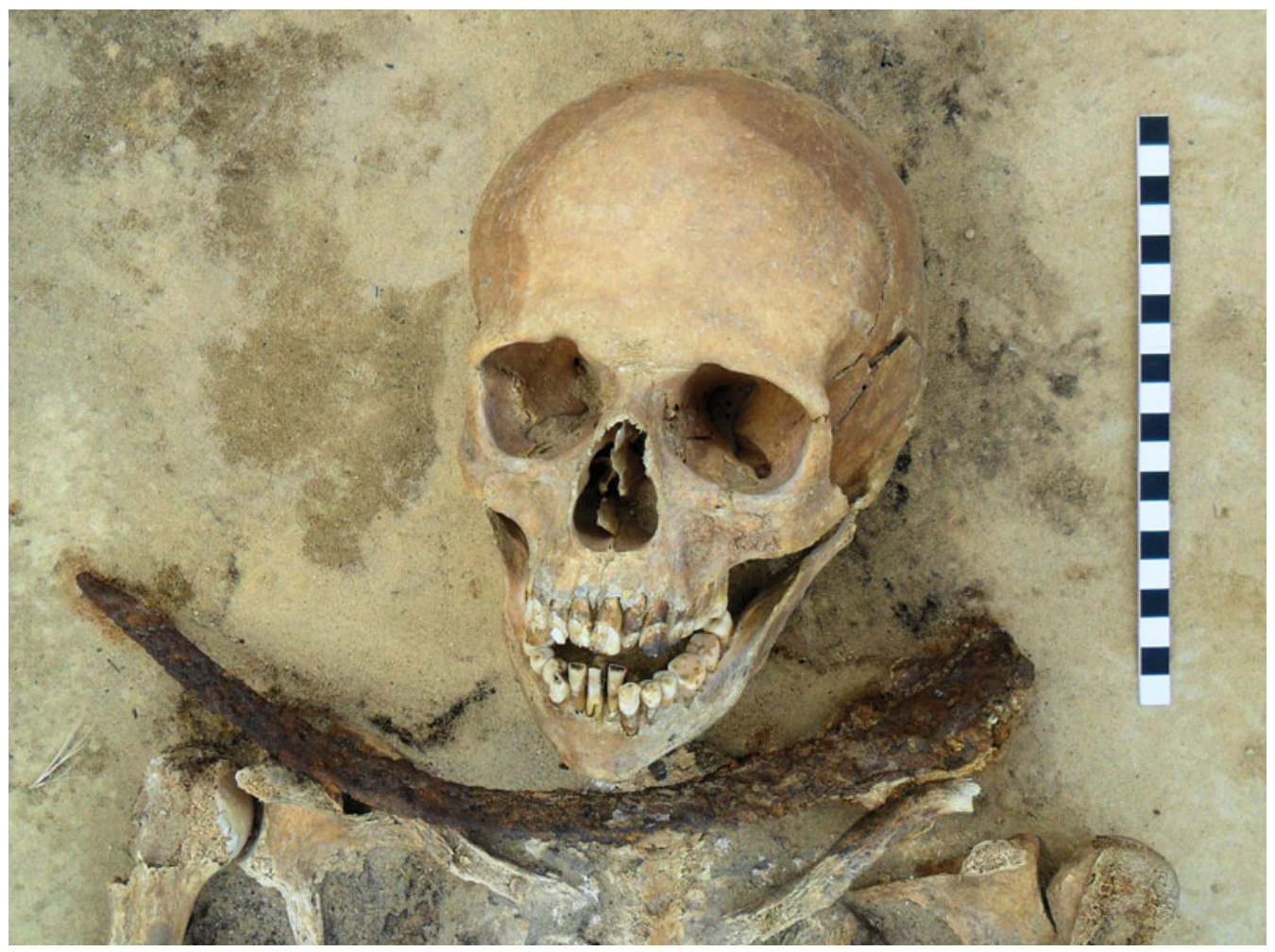

Figure 10. Skeleton of an adult female (49/2012) with a sickle on the throat.

\section{Sickle deposition in a mortuary context}

This is not the first time that sickles have been recorded in cemeteries of medieval and later periods in Central Europe. Borzova (2006) examined an assemblage of 72 sickles from secure contexts within graves dating from the seventh to tenth centuries AD in south-west Slovakia. Each burial had only one sickle and they were found in different positions along the entire length of the bodies of the deceased: near the head, on the chest, on the abdomen or pelvis, and on the upper and lower limbs. In all but seven graves the sickles were placed in some way directly in contact with the body of the deceased. In the majority of cases (39), sickles were located in the abdominal region across the pelvis or on one of the pelvic bones. Sickles were found near the head of the deceased in only three cases and none of these were placed across the neck (Borzova 2006: 214-16). Neither the custom of placing a sickle in the grave, nor its location on the body appears to correlate with age, sex, social status or ethnicity. The graves with sickles are scarce and they are otherwise unremarkable; orientation of the bodies in the graves and their grave goods do not differ from other graves in the cemetery and they do not occur in clusters or at marginal locations (Borzova 2006: 218). A similar diversity in the positioning of sickles or their fragments on bodies was recorded in several graves dating from the eleventh to thirteenth centuries in Poland (Kurasiński \& Janowski 2010: 82, 85-86) as well as in Medieval and Late Medieval Brandenburg in Germany (Biermannn 2004: 436-39, fig. 7; Wittkopp 2009: 189-90, fig. 5). Further early modern finds dated

(C) Antiquity Publications Ltd, 2015 
to the sixteenth to eighteenth centuries from Slovakia did not have sickles placed across the throat (Borzova 2006: 219).

\section{Interpretation}

The custom of burying the dead with iron sickles had its origins in the Early Middle Ages. This is evidenced by a concentration of interments with sickles in cemeteries from the sixth or seventh centuries to the eleventh century in the Carpathian Basin and the central Danube region in Slovakia, Hungary, Lower Austria and western Romania. It has been suggested that this practice may have been adopted by the Slavs, whose migrations spread the custom to the west and north-west (Kurasiński \& Janowski 2010: 87-88). Late Medieval and modern graves with sickles are known from northern Germany (Brandenburg) and Slovakia (Klein 2000; Biermannn 2004; Reichenbach 2004a, 2004b, 2006; Borzova 2006; Wittkopp 2009).

The reasons for providing the dead with sickles have not yet been clearly explained. In literature on the subject, the first of four major interpretations claims that an iron sickle placed in the grave was an indication that the deceased had followed an agricultural profession or had a personal connection to agriculture. That was thought to be particularly true of the female graves or burials where the sickle handle was located next to the hand. This explanation is rejected for the Drawsko site because the small number of burials associated with sickles is inconsistent with the social and economic importance of farming during this time (Slivenska 2004: 10; Borzova 2006: 217; Kurasiński \& Janowski 2010: 91). An alternative second explanation is that the graves with sickles could signify higher social status because those graves sometimes contained rich grave goods of other kinds. Reichenbach (2004a) considers a sickle in a funerary context to be a symbol of wealth and thus indicative of a higher material status. She believes that sickle graves from the Avar and Moravian periods discovered in Slovakia represent high-status burials. More specifically, Reichenbach argues that the sickle as a tool associated with cultivation of the land could be a 'symbol für landbesitz' (a symbol of landownership) (Reichenbach 2004a: 557).

Sickles can also be interpreted as weaponry. In Avar and Magyar societies, the sickle was regarded as a symbol of the military profession (Borzova 2006: 211; Reichenbach 2006: 76) and is often found in mortuary contexts along with weapons and metal elements of horse harness. Even in the later 'stages' of the early Middle Ages, a sickle mounted on top of a long stick was considered a dangerous weapon (Niesiołowska-Wędzka 1975: 174). It is assumed that during military expeditions these tools were handy for harvesting grass to feed the horses, so in mortuary contexts the sickle could be placed to represent horsemen (Kurasiński \& Janowski 2010: 91-92). These observations seem legitimate when the mortuary assemblages in question include other weapons and riding equipment. Complicating this interpretation, however, is the fact that sickles have also been found in the graves of women and children (Slivenska 2004: 8; Borzova 2006: 215-16; Reichenbach 2006: 88-89).

A fourth and final explanation relates sickles in graves to magic rituals and superstitions, the interpretation of which is directly derived from ethnographic data. According to Moszyński (1968), all Slavs believed that hard and sharp iron objects, especially stabbing and slashing tools, had apotropaic meaning: "It is a razor sharp scythe or sickle, stuck in the gate of the stalls that Byelorussian witches cut themselves with (hurt themselves with) 
on St John's Eve" (Moszyński 1968: 309-10). Sickles found in waterlogged archaeological contexts, for example, have been credited with anti-demonic or votive meaning (Chudziak 2005: 213). When placed in burials they were a guarantee that the deceased remained in their graves and therefore could not harm the living (Klein 2000: 141-42), but they may also have served to protect the dead from evil forces (Borzova 2006: 211, 218). According to folk wisdom, a sickle protected women in labour, children and the dead against evil spirits. It also had a role in rituals designed to counter black magic and witchcraft (Biermannn 2004: 440-41).

Anti-demonic notions are questioned by Wittkopp (2009), who analysed sickles from a cemetery at the Dominican monastery in Strausberg, Germany. She points out that the Dominicans were the order of preachers and inquisitors who were struggling to eradicate pagan customs and superstitions. Wittkopp prefers the biblical symbolism of the sickle. This tool is held by an angel in the announcement of the final judgment (Revelation 14: 6-20), as a symbol of the final harvest and as such is an attribute of the divine. In mortuary contexts, the sickle can refer to the piety of the deceased symbolising that they were the tool of God' ('Werkzeuge Gottes') and explaining at the same time the rarity of these objects in burial contexts (Wittkopp 2009: 191-93).

The placing of the sickle's cutting blade across the throat of the deceased in the Drawsko burials clearly indicates a gesture of confinement of the deceased in the grave under the threat of slitting their throat. The magical and ritual meaning of this gesture seems beyond doubt. In Drawsko we seem to have evidence of two kinds of funerary symbolism. On one hand, the sickle holds the dead in the grave; on the other, it prevents evil forces from tormenting their souls. At the same time, this iron tool might symbolise a passage from earthly life to the afterlife. Besides apotropaic properties such as hardness and sharpness, iron, the material that undergoes transformation in fire, has been a symbol of transition for millennia (Kowalski 1998: 646-47).

\section{Discussion}

For centuries, most aspects of spiritual and ritual life in Poland, and in particular death and funerary rites, have been the domain of Christian eschatology and the liturgy of the Catholic Church. Alongside the established canon, however, and mainly in rural areas, parallel folk beliefs existed that combined elements of Christianity with aspects of old Slavic pagan faith. This dichotomy between the official Christian dogma, which was, until the twentieth century, expressed only in Latin - a language that was incomprehensible to many — and the still-preserved remains of pagan beliefs is often referred to a 'dvoeverie' (or dual faith) (Pełka 1987: 12). The Drawsko interments indicate that at certain historical moments, beliefs that conflicted with commonly accepted burial rites resurfaced. Without a doubt, one of those historical moments was the seventeenth century; it brought numerous devastating wars to Poland, which lasted for most of the century and put the country in turmoil. These wars were followed by hunger, pestilence and poverty. The development of the Counter-Reformation was a significant turning point as it brought cultural and intellectual regression, religious fanaticism and a growing climate of terror, deliberately stoked by Catholic clergy spreading fear of the devil and witchcraft. As a result, old beliefs and superstitions came back to life

(C) Antiquity Publications Ltd, 2015 
(Baranowski 1950: 34-35). A major component of the folk belief system was demonology, which influenced the spiritual life of Polish rural areas from the Middle Ages until the early twentieth century. Demonology affected life directly or indirectly at both an individual and a community level (Pełka 1987: 5-6). Ethnographic evidence should therefore provide an insight into the social role of those buried with sickles and their cause of death. In his Antropologia kultury wsi polskiej XIX wieku (Cultural anthropology of the Polish rural areas in the nineteenth century), Stomma (2000) analysed hundreds of folk demonological accounts passed from generation to generation and recorded by ethnographers studying rural areas. The creatures that populate this imaginary world can be divided into five categories. In addition to a variety of mythical beings, he distinguishes two categories of demons that involve the living. The first comprises demons that are incarnations of the deceased while the second includes those among the living who had certain supernatural powers. These people were members of the local community, known to their neighbours by name. It was the nature of their deaths, or the peculiar knowledge and skills cultivated in their lifetime, that made their contemporaries assign 'demonic' attributes to them (Stomma 2000: 100, 102).

Incarnations of the dead arose from those who died a 'bad death'. This included those who met a violent end, or whose demise was not preceded and confirmed by appropriate rituals or those who died during a ritually important moment of their life. These were people who had left one state of being (life) and entered the next state (death), but without the transition being marked by the appropriate rites in a ritualistic and magical sense. In the public perception, they were beyond any particular state, detained between the worlds of the living and the dead; they became demons. There are at least 14 demons into which the soul of the deceased person could be transformed (Stomma 2000: 101-102). According to 500 folk accounts from the nineteenth century, the circumstances of death associated with demons are as follows: in $20.2 \%$ of cases death occurred by drowning; $18 \%$ were deaths without baptism; $11 \%$ were miscarried children; $8.4 \%$ had met a violent death; $8.6 \%$ were suicides; $8 \%$ were deaths at the individual's own wedding; $7.6 \%$ were hanged; $7.6 \%$ were stillborn children; $2.8 \%$ were women who died postpartum; $2.8 \%$ were betrothed people who died during their wedding or just before it; $2 \%$ were women who died in labour; and 3\% fell into the 'other' category (Stomma 2000: 161). The 'other' category includes people considered as demonic because they had, or claimed to have, certain abilities or skills of a supernatural character and of whom the local community was afraid. These might include witches, werewolves, people with the 'evil eye', who could cast spells and ptanetnik (people with the ability to influence weather events).

Among those buried with sickles at Drawsko who might have died a 'bad death', the most probable candidate is the teenage girl (grave 6/2012, Figures $7 \& 8$ ). It is possible that she drowned, committed suicide, was murdered or died another kind of violent and untimely death. Deceased people whose souls might have been trapped between the two worlds were often buried outside cemeteries in marginal locations. These would normally include the village limits, areas in the vicinity of fences or walls, underneath thresholds, by the roadside or on the waterfront, and in zones between fields. According to folk accounts, these liminal locations were the places where transformed demons most frequently appeared (Stomma 2000: 103). But perhaps in this we reach an explanation of the meaning of a sickle placed in a coffin. The dead from Drawsko, no matter how demonic they may have been thought 
by their fellow villagers, were after all buried with Christian rites in a cemetery in hallowed ground. Despite this adherence to the recognised funerary rites, the problem of demons remained in the collective consciousness, and the presence of the sickle was meant to solve it.

The age of the woman from grave 60/2012 (50-60 years, Figures 5 \& 6) suggests a natural death, but the presence of a sickle on her hips, the coin in her toothless mouth and the stone on her neck indicate that she was also thought to have demonic features as well. Coins in graves do not necessarily have an apotropaic meaning; the custom of putting a coin in the mouth or the hand of the deceased has a long history and its symbolism in a funerary context is rather ambiguous. But in this case we are dealing with a burial package (sickle, stone and coin), which seems to confirm the uniqueness of this interment. This person must have been someone special in the local community, perhaps because of her skills or abilities. Was she a witch? Were we to choose this interpretation, it should be emphasised that she did not necessarily meet the popular stereotype of a witch, i.e. accused of evil acts against the community, such as casting spells, using charms, inflicting damage and the like. This term may also have included herbalists, healers, fortune-tellers and midwives; all of whom had skills unavailable and incomprehensible to the wider community, inspiring respect as much as fear. As a consequence, however, their rural community may have feared their return after death in demonic form.

Another group of people mentioned by Stomma (2000) comprises those who were considered demonic because they were not agriculturalists, because they followed a different religion or came from elsewhere; in essence, they were strangers to the rest of the community. In the nineteenth century, few peasants ever left their farms, and hardly anyone would leave the confines of their village. Administrative, religious or educational contact with other villages and towns was very limited. 'We are farmers'; 'we are Catholics'; 'we are locals'; these seem to be the most prevalent criteria of peasant self-definition during this time. Multilateral isolation was a fundamental feature of folk culture of the nineteenth century as well as at the turn of the twentieth century (Stomma 2000: 42). There is no reason to believe that situation was different 200 years earlier. So, according to the folk mentality, a stranger was anyone who did not live in the village, anyone who did live in the village but was not born there, and anyone who followed a different trade or practised a different faith. According to folk beliefs, non-agricultural occupations often entailed strange and mysterious effects. This was a result of the fact that peasants found most of these trade skills hard to comprehend. Anyone who was not a farmer was suspected of relations with demonic forces and even of selling their soul to the devil. Millers, innkeepers, thieves, hunters, potters and blacksmiths were all thought to benefit from intimacy with evil forces (Stomma 2000: 34-35).

Although the exact cause of death cannot be determined, it is possible that those buried with sickles at Drawsko (graves 28/2008, 24/2009, 49/2012), who died in the prime of life, were included in the category of strangers, non-farmers or religious dissenters. We are unable to say which of the criteria of strangeness is indicated here: one or perhaps all three of them. Certainly they were not foreigners or migrants from remote corners of the Polish-Lithuanian Commonwealth; preliminary analysis of radiogenic strontium isotopes from dental enamel sampled from 60 individuals including those buried with sickles shows that ${ }^{87} \mathrm{Sr} /{ }^{86} \mathrm{Sr}$ values (Figure 11) do not differ from local strontium ratios available for the Drawsko area, which suggests a local population (Gregoricka et al. 2014). These people most probably lived their (C) Antiquity Publications Ltd, 2015 


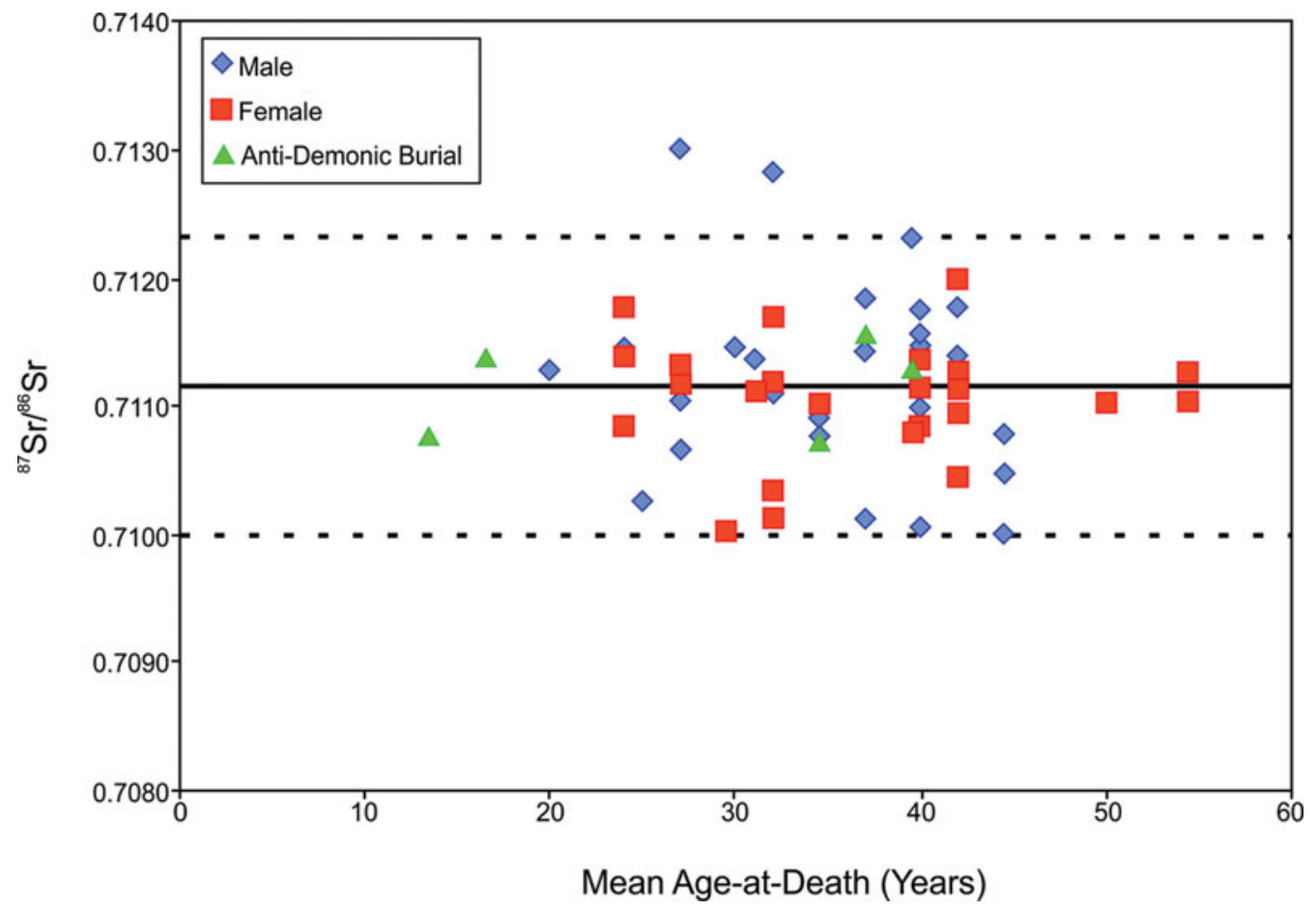

Figure 11. Strontium isotope ratios from human dental enamel at Drawsko (after Gregoricka et al. 2014).

whole life either in Drawsko or in the nearby villages. It is unlikely, but cannot be excluded, that they died a sudden and unnatural premature death. In all five cases from Drawsko it is impossible to exclude any combination of the demonic features described above, so that an individual not only died a violent death, but was also perceived as a stranger by the rest of the community due to their profession, religion or place of birth. Neither can we exclude an unusual, terminal health condition that leaves no trace on the bones but was odd enough to make the community suspect that the deceased was demonic. We hope that these doubts will be removed by biomolecular analyses.

According to Pełka (1987), there were several physical characteristics that could make an individual demonic in common perception. These included, for instance, a large head, an exceptionally hairy body, a monobrow (synophrys), a red complexion, a double row of teeth and being born in the amniotic sac. This group also included people stigmatised by the local community because of visible body deformities caused by an accident or illness, such as a limp, a humped back or rickets (Pełka 1987: 168). Although body hair or skin colour is not recognisable from the bone material, we can definitely affirm that the dead from Drawsko have no obvious physical deformation that could cause such stigmatisation (Betsinger 2013). It seems that the dead were treated the way that they were for cultural and behavioural reasons related to who they were in life, how they lived or the circumstances of their death, rather than because of a physical disability. 


\section{Conclusions}

The sickle burials of Drawsko so far have no direct analogy in Central Europe, either in the Middle Ages or the following centuries. They are clear evidence of anti-demonic funerary practice. Folk culture has created a complex system of prohibitions and restrictions isolating the people who died a 'bad death', and therefore remain in the intermediate transitional state, from the rest of the community or reducing their contact with the living to a specific repertoire of ritual behaviour (Stomma 2000: 100, 102). Confining the deceased in the grave by means of a sickle may have been a measure to prevent the demonised soul threatening the living, or could have been a reference to biblical symbolism in an attempt to prevent the soul from becoming demonised. The latter approach can serve as an extension of the interpretation of the sickle as the 'tool of God' proposed by Wittkopp (2009: 193).

We deliberately dismiss the interpretation of a revenant (i.e. vampire). As noted above, there are a variety of demons into which the soul of the deceased may be transformed according to folk wisdom, with upiór (often referred to as a vampire) being just one of those (Stomma 2000: 101-102). Thus, we prefer to classify the interments from Drawsko as 'antidemonic'. Moreover, the sickle interments from Drawsko have none of the characteristics of so-called 'anti-vampiric practices'. They follow a conventional Christian burial pattern; the graves were not re-opened and the bodies of the dead were not desecrated. On the contrary, they were interred in hallowed ground, amongst the other deceased members of the community, and according to custom, which indicates that they had not been social outcasts. A similar observation is made by Borzova in relation to the mortuary sickle finds from the early Middle Ages in Slovakia (Borzova 2006: 218).

Folk demonology is an abundant source of information on social interactions. The circumstances of death that could make a deceased person demonic in the eyes of their community can often be seen in the archaeological record and provide information about individual identities. The same is true of people considered demonic because of their lifestyle, who were believed to have certain fearful abilities of a supernatural character. It is now for archaeological science, particularly biomolecular analyses, to narrow down the question of what lay behind the decision to bury the dead in Drawsko with sickles: cultural and behavioural factors; social stigmatisation due to physical appearance; or different geographical origins.

\section{Acknowledgements}

The authors would like to thank the Museum of Czarnków and the Slavia Foundation for their continuous support of the excavations in Drawsko as well as all the members of the Slavia Project Team and the Slavia Project Students for their dedication and hard work. We would particularly like to thank Maria Kaczmarek, Jan Pertek, Tracy K. Betsinger, Amy B. Scott, Marta Gwizdała, Ewa Loba-Bronowicka, Michał Rozwadowski and Danuta Banaszak. We are also grateful to Matthew J. Boyd and Ilona Polcyn for their critical readings of the text and many useful remarks.

\section{References}

Baranowski, B. 1950. Kontrreformacja $w$ Polsce XVI-XVIII $w$. Warszawa: Czytelnik.
Betsinger, T. 2013. Drawsko 2008-2013 pathological review. Unpublished report prepared for the Slavia Foundation, Lednogóra. 
BiermanNN, F. 2004. Schlüssel und Sicheln in spätmittelalterlichen Gräbern Brandenburgs. Archäologisches Korrespondenzblatt 34: 435-46.

Borzova, Z. 2006. Kosáky v hroboch z obdobia včasného stredoveku na Slovensku. Slovenská Archeólogia 54: 209-37.

CHUDZIAK, W. 2005. Z badań nad funkcją społeczną sierpów i półkosków na ziemiach słowiańskich we wczesnym średniowieczu. Archeologia Historica Polona 15: 201-18.

Dernoga, M. \& E. GajdA. 2004. Grób z młodszego okresu przedrzymskiego w Drawsku, gm. Drawsko, woj. Wielkopolskie, in H. Machajewski (ed.) Kultura jastorfska na Nizinie Wielkopolsko-Kujawskiej: 259-63. Poznań: Biblioteka Wielkopolskich Sprawozdań Archeologicznych.

GARDEŁA, L. \& K. KAJKOWSKI. 2013. Vampires, criminals or slaves? Reinterpreting 'deviant burials' in early medieval Poland. World Archaeology 45: 314-32. http://dx.doi.org/10.1080/00438243.2013.799040

GregorickA, L.A., T.K. Betsinger, A.B. SCOTt \& M. POlCYN. 2014. Apotropaic practices and the undead: a biogeochemical assessment of deviant burials in post-medieval Poland. PLoS ONE 9(11): e113564. http://dx.doi.org/10.1371/journal.pone.0113564

KLEIN, D. 2000. Sichel und Schlüssel gegen das Unheil.Bestattungen in Nebigau, Landkreis Elbe-Elster. Archäologie in Berlin und Brandenburg 1999: 141-42.

KoperKIEWICZ, A. 2010. Święci czy przeklęci? Kilka refleksji o anomaliach w pochówkach wczesnośredniowiecznych, in K. Skóra \& T, Kurasiński (ed.) Wymiary inności: Nietypowe zjawiska w obrzędowości pogrzebowej od pradziejów po czasy nowożytne. Acta Archaeologica Lodziensia 56: 65-77.

KOWALSKI, P. 1998. Leksykon znaki świata. Omen, przesad, znaczenie. Warszawa-Wrocław: Wydawnictwa Naukowe PWN.

KurAsińSKI, T. \& A. JANOWSKI. 2010. Rolnik, wojownik czy 'odmieniec'? Próba interpretacji obecności sierpów w grobach wczesnośredniowiecznych na terenie ziem polskich. Acta Archaeologica Lodziensia 56: 79-96.
MoszyŃsKI, K. 1968. Kultura Ludowa Stowian (volume 2): Kultura duchowa. Warszawa: Ksiązka i Wiedza.

NiesIOŁOWSKA-WĘDZKA, A. 1975. Sierpy, in G. Labuda \& Z. Stieber (ed.) Stownik Starożytności Stowiańskich 5: 173-74. Wrocław: Ossolineum.

PeŁKa, L.J. 1987. Polska demonologia ludowa. Warszawa: Iskry.

RAJEWSKI, Z. 1974. Świętawoda u Słowian - źródła, rzeki, jeziora. Slavia Antiqua 21: 111-17.

REICHENBACH, K. 2004a. Sicheln in mittelalterlichen Gräbern in der Slowakei. Archeologia Historica 29: 549-60.

- 2004b. Sicheln als mittelalterliche und neuzeitliche Grabbeigaben in der Slowakei. Leipziger online-Beiträgezur Ur- und Frühgeschichtlichen Archäologie 10: 1-14.

- 2006. Frühmittelalterliche Grabfunde mit Sichelbeigabe im Gebiet der Slowakei, in J. Zábojnik (ed.) Aevum Medium: Zborník na počest Jozefa Hošs a: 75-94. Bratislava: Univerzity Komenského, Bratislava.

SLIVENSKA, Z. 2004. The sickles in graves during the period of early middle ages from the territory of Slovakia. Annales Universitatis Apulensis, Series Historica 8: 7-11.

STANASZEK, Ł.M. 1998. Praktyki antywampiryczne w XI wieku stosowane na terenie cmentarzyska szkieletowego na Wzgórzu Swiętojakubskim w Sandomierzu. Biuletyn Antropologiczny 2: 18-31.

Stomma, L. 2000. Antropologia kultury wsi polskiej XIX w. Gdańsk: Tower Press.

The Holy Bible: King James version 2000. Available at: http://www.bartleby.com/108/66/14.html\#6-20 (accessed 15 July 2015).

TSALIKI, A. 2008. Unusual burials and necrophobia: an insight into the burial archaeology of fear, in E.M. Murphy (ed.) Deviant burial in the archaeological record: 1-16. Oxford: Oxbow.

Wiтtкоре, B. 2009. Der Dominikanerfriedhof in Strausberg. Sonderbestattungen, Sicheln und ihre Interpretation. Ethnographisch-archaologische Zeitschrift 50: 179-95.

ŻYDOK, P. 2004. Wczesnośredniowieczne pochówki antywampiryczne, in Z. Kobyliński (ed.) Hereditatem Cognoscere: Studia i Szkice dedykowane Profesor Marii Miśkiewicz: 38-66. Warszawa: Państwowe Muzeum Archeologiczne.

Received: 8 October 2014; Accepted: 7 January 2015; Revised: 16 January 2015 